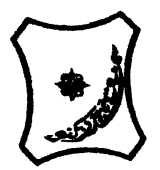

Bayero Journal of Pure and Applied Sciences, 13(2):117 - 124

Received: March, 2020

Accepted: November, 2020

ISSN 2006 - 6996

\title{
MICROBIAL CHANGES DURING THE FERMENTATION OF BAOBAB (Adansoniadigitata) FRUIT PULP YOGHURT
}

\author{
${ }^{*}{ }^{1}$ Zumunta, J. D., ${ }^{2}$ Umar, A. F. and ${ }^{2}$ Agbo, V. \\ ${ }^{1}$ Integrated Science Department, Aminu Saleh College of Education Azare, Bauchi State, Nigeria \\ ${ }^{2}$ Department of Microbiology, Abubakar Tafawa Balewa University (ATBU) Bauchi. Bauchi State, Nigeria \\ Correspondence Author: zumuntajonathan@gmail.com (08068968980)
}

\section{ABSTRACT}

This study was conducted to assess the microbial changes during the fermentation of Baobab (Adansoniadigitata)fruit pulp yoghurt. The Baobab fruit pulp yoghurt was prepared in the Laboratory using the conventional method. Lactobacillus bulgaricus and Streptococcus thermophilus were used as starter cultures while a control was produced without the starter cultures. de Man Rogosa Sharpe (MRS) agar was used to culture lactic acid bacteria. The microbialload, succession and percentageoccurrences were determined usingstandard methods. The total aerobic bacterial count wasfound to be within the range of $1.9 \times 10^{3}-$ $1.4 \times 10^{5} \mathrm{cfu} / \mathrm{ml}$. Thelactic acid bacteria and fungal count ranges were $4.5 \times 10^{3}-7.5 \times 10^{3}$ $\mathrm{cfu} / \mathrm{ml}$ and $8.0 \times 10^{1}-2.8 \times 10^{4} \mathrm{cfu} / \mathrm{ml}$ respectively. At the end of fermentation time, there was significant difference between the test and control Baobab yoghurt at $P<0.05$. Lactic acid bacteria recorded the highest count of $6.2 \times 10^{4}$ and $7.5 \times 10^{3} \mathrm{cfu} / \mathrm{ml}$ in the test and control respectively.Bacillus species,Staphylococcus aureus, Lactobacillus bulgaricus, Streptococcus thermophilus and Micrococcus species were the bacteria isolated while the fungal isolates were Saccharomyces cerevisiae and Hansenula species.Lacbacillusbulgaricus, Streptococcus thermophilus,Bacillus speciesand Saccharomyces cerevisiae were the only microorganisms found at the end of fermentation time. The study obtained low microbial count and isolated less number and type of microorganisms from Baobab fruit pulp yoghurtbecause of the antimicrobial effect of baobab pulp and pasteurization treatment.Based on the results of this study, Baobab fruit pulp yoghurt can be said to be of good microbiologicalquality for human consumption. The industrial use of Baobab fruit pulp in the production of yoghurt is recommended.

Keywords: Baobab, Fermentation, Fruit pulp, Microbial changes and Yoghurt

\section{INTRODUCTION}

Yoghurt is one of the most popular fermented dairy products widely consumed all over the world. It is obtained by lactic acid fermentation of milk by the action of a starter culture containing Streptococcus thermophilus and Lactobacillus delbruckii spp. Bulgaricus (Helmenstine, 2016). It can also bemade by using a portion from the former fermentation - backslopping. The role of these two genera in yoghurt manufacture can be summarized as milk acidification and synthesis of aromatic compounds (Adams and Moss, 2009).

In Nigeria, it is a popular drink due to its nutritional, probiotic and organoleptic characteristics (De et al., 2014). The high pH and low acidity may be due to the fact that there is no proper system of culture dosage in unbranded yogurt, which largely affects the acidity of the final yogurt.Milk derived from animal such as cow milk, is high in nutrients such as protein, fat, carbohydrates, vitamins and minerals necessary food required by microorganisms (Efiosa et al., 2017).

Baobab (Adansoniadigitata) fruit pulp yoghurt is made by combining commonly available commercial animal milk with milk obtained from Baobab fruit pulp. 
BAJOPAS Volume 13 Number 2,December, 2020 The pulp, seeds and the fibre are separated by sieving to produce a fine powdery pulp (Baobab Fruit Company Senegal, BFCS, 2011). The Baobab Pulp is $100 \%$ natural and organic, no chemicals or preservatives added. It has a unique pleasant flavor reminiscent of pear with a mild slightly acidic after taste due to its high percentage of organic acids such as citric acid, tartaric acid, malic acid, succinic acid and ascorbic, with $\mathrm{pH}$ 3.3(Abdallaetal., 2010; BFCS, 2011).

Yoghurt has milk as a raw material for its production. Milk even in powdered form has been reported to support the growth of microorganisms for instance Staphylococcus aureus (Efiosa et al., 2017).

There have been a number of foods borne illnesses resulting from the ingestion of raw milk, or dairy products made with milk that was not properly pasteurized or was poorly handled causing post-processing contamination (Eze et al., 2014). The following bacterial pathogens are still of concern today in raw milk and other dairy products: Bacillus cereus, Listeria monocytogenes, Yersinia enterocolitica, Salmonella spp, Escherichia coli 0157:H7 and Campylobacter jejuni (De et al., 2014).It should also be noted that moulds, mainly of species of Aspergillus, Fusarium, and Penicillium can grow in milk and dairy products. If the conditions permit, these moulds may produce mycotoxins which can be a health hazard (Bhattacharjee, 2013).

Dirisu et al. (2015) reported that related researches have shown that most yoghurt sold in Nigerian markets are contaminated with pathogenic bacteria such as E. coli, Staphylococcus aureus, Bacillus spp and moulds, such as Rhizopus spp., Aspergillus spp. etc Yoghurt also serves as a medium for the growth of microorganisms due to its high nutritional content hence it is liable to contamination. Moulds and yeast are the primary contaminants in yoghurt.

Fungi growing in yoghurt utilize some of the acid, which will invariably reduce the acidity and hence favour the growth of putrefactive bacteria (Dirisu et al., 2015) or other pathogenic organisms such as Staphylococcus aureus. Caplice and Fitzgerald (1999) noted that at the beginning of the fermentation step, the food is vulnerable to contamination since it is not acidic. It is known that pathogenic microorganisms normally found in food will not be able to grow in an acid environment, which is at $\mathrm{pH}$ below four. This acidity is normally found in lactic acid fermented food (Adams and Moss, 2009).

Several authors have reported the effect of fermentation on the microbial and / or biochemical changes of food products: Parkouda et al.(2015) reported Biochemical changes associated with the fermentation of baobab seeds in Maari. Eze et al. (2014) investigated the Biochemical and Microbiological Changes associated with Fermenting African Oil Bean (Pentaclethramacrophylla Benth) Seeds; Achi et al.(2007)worked on Microbiological and Chemical Changes during Fermentation of Crabs for ogirinsiko Production.

It is postulated that the organic acids in Baobab pulp milk and lactic acids produced during fermentation of Baobab fruit pulp Yoghurt could be effective against the growth of spoilage Microorganisms. This study was conducted to assess microbiological changes during the fermentation of this new food (Baobab Fruit Pulp Yoghurt).

\section{MATERIALS AND METHODS Laboratory Preparation of baobab fruit pulp yoghurt}

The traditional method of preparingbaobab fruit pulp yoghurtwas employed in the laboratory (Ekeetal.,2013).

The large lumps of the pulp containing the seeds and fibre were carefully pounded without breaking the seeds using pestle and mortar to loosen the content. The pulp, seeds and the fibre were separated by sieving to produce a fine powdery pulp (BFCS, 2011).

Powdered milk (300g) was dissolved in one and half litres $(1.5 \mathrm{~L})$ of water and $100 \mathrm{~g}$ of baobab pulp was dissolved in one litre $(1 \mathrm{~L})$ of water. The two solutions were pasteurized separately at $80-85^{\circ} \mathrm{C}$ for 15 minutes after which they were then mixed together. The sample was inoculated with culture of actobacillusbulgaricus and Streptococcus thermophilus and incubated at room temperature for 15 hours. A control was made in the same way without the use of starter cultures. 
BAJOPAS Volume 13 Number 2,December, 2020

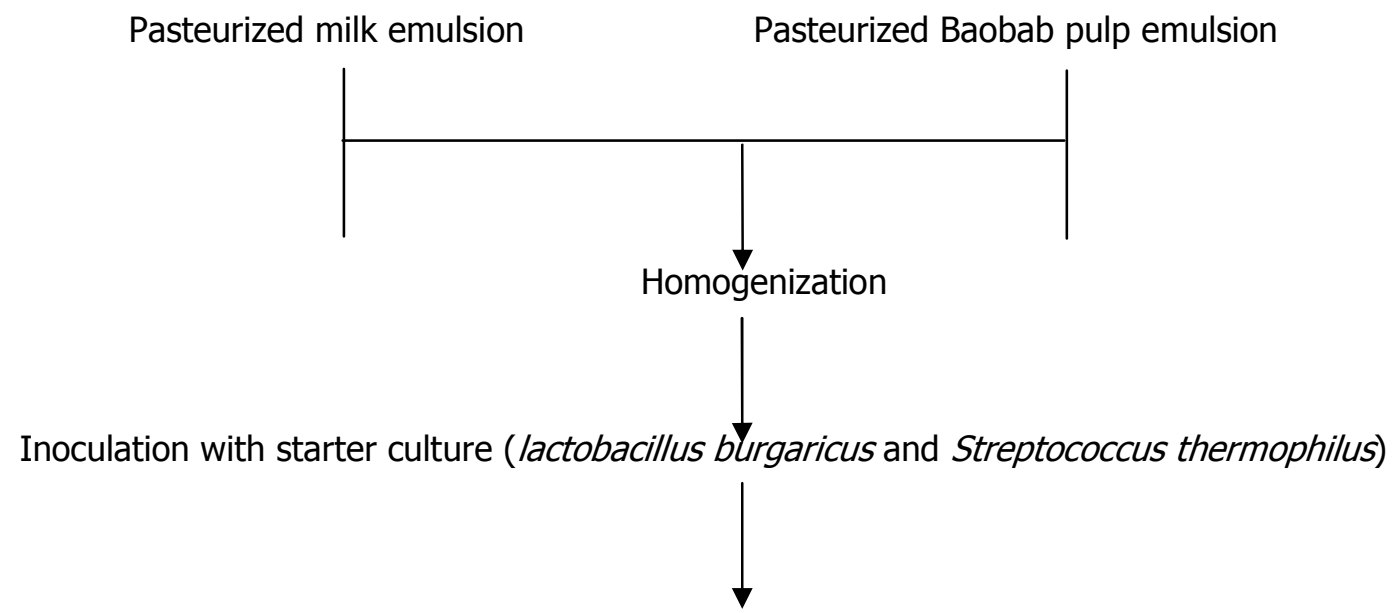

Incubation at $27-30^{\circ} \mathrm{C}, 15 \mathrm{Hrs}$

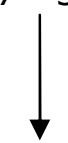

Cooling $25^{\circ} \mathrm{C}$

Baobab fruit pulp yoghurt

Fig.1: Flow chart for production of Baobab fruit pulp Yoghurt (Eke et al., 2013)

\section{Microbiological analysis \\ Serial dilution}

One $\mathrm{ml}$ of the sample was thoroughly mixed with $9 \mathrm{ml}$ of normal saline water as diluents in a McCartney bottle and the content was thoroughly shaken. Subsequent serial dilutions $\left(10^{-2}, 10^{-3}, 10^{-4}\right.$ and $10^{-5}$ ) were made from this solution by adding serially $1 \mathrm{ml}$ of solution from preceding concentration to $9 \mathrm{ml}$ of diluents, using sterile syringe.

\section{Isolation of Bacteria}

A $0.1 \mathrm{ml}$ of various dilutions were transferred separately to agar plates using streak method in triplicates of Nutrient Agar (for total aerobic bacteria), de Man Rogosa Sharpe (MRS) agar (for lactic acid bacteria), Salmonella Shigella agar (SSA) for isolation of Salmonella and Shigella species (Ezeet al., 2014). Bacteria counts were made on nutrient agar plates incubated at $37^{\circ} \mathrm{C}$ for 24 hours. The total number of colonies developed were counted and expressed as cfu/ml of the original sample. Colonies were differentiated on the basis of morphology and counts of different colonial types. For specific counts of de Man Rogosa Sharpe (MRS) Agar, plates were incubated at $37^{\circ} \mathrm{C}$ for $3-4$ days (Ezeet al., 2014).

\section{Identification of Bacteria}

Colonies obtained after incubation were aseptically sub-cultured on Nutrient agar and were incubated for 24 hours at $37^{\circ} \mathrm{C}$. The cultural characteristics of isolates on the agar plates were observed.The isolated colonies were then gram stained to differentiate bacteria into gram positive and negative. Different biochemical testswere carried out using standard methods described by Vaughan (1994) andpure cultures of the different organisms identified were sub-cultured and preserved on agar slants at refrigeration temperature $\left(4^{\circ} \mathrm{C}\right)$ (Ezeet al., 2014).

\section{Isolation andIdentification of Fungi}

A $0.1 \mathrm{ml}$ of various dilutions were transferred separately to Potato Dextrose agar (PDA) using streak method in triplicates (Ezeet al., 2014). The plates were incubated at room temperature $\left(25^{\circ} \mathrm{C}\right)$ for 5 to 14 days. 
BAJOPAS Volume 13 Number 2,December, 2020 The total number of colonies developed were counted and expressed as $\mathrm{cfu} / \mathrm{ml}$ of the original sample. The method described by Ibrahim and Rahma (2009) was adopted for identification of the fungi using Lactophenol cotton blue. The species encountered were identified in accordance with Cheesbrough (2000) and Ellis, et al. (2007).

\section{Monitoring microbial changes}

The microbial changes were monitored by Periodical $\mathrm{pH}$ measurement to show $\mathrm{pH}$ decrease or increase at three hourly, Periodical Temperature measurements to note increase or decrease at three hours interval, Determination of total acidity (lactic acid) at three hours interval and Microbial analysis at three hours interval.

\section{Statistical Analysis}

The results were presented in tables and graphs. Analysis of Variance (ANOVA) was used to obtain the effect of fermentation time on the product (Baobab fruit pulp Yoghurt) as well as compare the difference between the test and control group at $5 \%$ significance level. The statistical calculations were done using SPSS software version 22.0.

\section{RESULTS AND DISCUSSION}

Table 1shows the microbial count obtained from the test and control samples of Baobab fruit pulp yoghurt which were taken at the interval of every three hours for the period of fifteen hours. There was no growth of Salmonella and Shigella in both the test and control group. Highest count of totalaerobic bacteria was recorded at the onset ( 0 hour) thatis $1.4 \times 10^{5}, 2.4 \times 10^{4} \mathrm{cfu} / \mathrm{ml}$ in the test and control group respectively. The lactic acid bacterial count recorded the highest in the fifteenth hour of $6.2 \times 10^{4}$ and $7.5 \times 10^{3} \mathrm{cfu} / \mathrm{ml}$ in the test and control respectively. Highest fungal count was observed in the third hour of fermentation $\left(2.8 \times 10^{4}\right)$ and at the onset of fermentation $\left(1.8 \times 10^{4}\right)$ in the test and control respectively. There was significant difference between the test yoghurt and the control yoghurt at $P<0.05$ toward the end of fermentation.

Table 2 below shows the succession of microorganisms isolated from Baobab Fruit Pulp Yoghurt. The organisms isolated included Bacillus species. Staphylococcus aureus, Lacbacillus bulgaricus, Saccharomyces cerevisiae, Streptococcus thermophilus, Hansenula species and Micrococcus species. Bacillus species, Lacbacillusbulgaricus, Streptococcus thermophilus and Saccharomyces cerevisiae were found from the beginning to the end of fermentation. Micrococcus species appeared in the third hour of fermentation and disappeared after nine hours. Staphylococcus aureuswas encountered at the onset and disappeared after six hours of fermentation. Hansenula species endured till after twelfth hours when it got weeded out.

The occurrence of microbial isolates which are shown in Table 3 revealed that Lactobacillus species were the most predominant organism encountered while Bacillus speciesoccurred less in the Baobab fruit pulp yoghurt sample during the investigation period. The table gave the percentage occurrences of microbial isolates obtained from Baobab Fruit Pulp Yoghurt in which Lactobacillus species had the highest frequency of occurrence $(31 \%)$ while Bacillus species had the lowest frequency of occurrence (9.2\%). 
BAJOPAS Volume 13 Number 2,December, 2020

Table 1: Microbial count of Baobab fruit Pulp Yoghurt

\begin{tabular}{|c|c|c|c|c|c|c|c|}
\hline \multirow{2}{*}{$\begin{array}{c}\text { Microbial Count } \\
(\mathrm{cfu} / \mathrm{ml})\end{array}$} & \multirow[t]{2}{*}{ GROUP } & \multicolumn{6}{|c|}{ Time (hrs) of fermentation } \\
\hline & & $\mathbf{0}$ & 3 & 6 & 9 & 12 & 15 \\
\hline $\mathrm{TBC}$ & $\begin{array}{c}\text { Test } \\
\text { Control }\end{array}$ & $\begin{array}{c}1.4 \times 10^{5} \pm 1.0 \times 10^{3} \\
1.3 \times 10^{4} \pm 1.0 \times 10^{2 \mathrm{bcde}}\end{array}$ & $\begin{array}{c}1.1 \times 10^{4} \pm 1.0 \times 10^{2} \\
2.2 \times 10^{4} \pm 1.0 \times 10^{3 b c}\end{array}$ & $\begin{array}{l}1.9 \times 10^{4} \pm 1.0 \times 10^{3} \\
2.4 \times 10^{4} \pm 1.0 \times 10^{3 b}\end{array}$ & $\begin{array}{l}6.8 \times 10^{3} . \pm 1.0 \times 10^{2 a} \\
1.7 \times 10^{4} \pm 1.0 \times 10^{3 c}\end{array}$ & $\begin{array}{l}4.2 \times 10^{3} \pm 1.0 \times 10^{2 a} \\
2.7 \times 10^{3} \pm 1.0 \times 10^{2 d}\end{array}$ & $\begin{array}{l}2.6 \times 10^{3} \pm 1 \times 10^{2} \\
1.9 \times 10^{3} \pm 1 \times 10^{2 \mathrm{e}}\end{array}$ \\
\hline SSC & Test & NG & NG & NG & NG & NG & NG \\
\hline & Control & NG & NG & NG & NG & NG & NG \\
\hline LBC & Test & $4.5 \times 10^{3} \pm 1.0 \times 10^{2}$ & $5.3 \times 10^{4} \pm 1.0 \times 10^{2}$ & $7.5 \times 10^{3} \pm 1.0 \times 10^{2 a}$ & $8.0 \times 10^{3} \cdot \pm 1.0 \times 10^{2 a}$ & $3.6 \times 10^{4} \pm 1.0 \times 10^{3}$ & $6.2 \times 10^{3} \pm 1 \times 10^{3}$ \\
\hline FC & $\begin{array}{l}\text { Control } \\
\text { Test } \\
\text { Control }\end{array}$ & $\begin{array}{c}0.0 \pm 0.0^{b} \\
1.7 \times 10^{4} \pm 1.0 \times 10^{3 \mathrm{ae}} \\
1.8 \times 10^{4} \pm 1.0 \times 10^{3 \mathrm{de}}\end{array}$ & $\begin{array}{c}0.0 \pm 0.0^{b} \\
2.8 \times 10^{4} \pm 1.0 \times 10^{3 a} \\
1.7 \times 10^{4} \pm 1.0 \times 10^{3 d}\end{array}$ & $\begin{array}{c}6.1 \times 10^{3} \pm 1.0 \times 10^{2 \mathrm{~cd}} \\
1.9 \times 10^{3} \pm 1.0 \times 10^{2 \mathrm{bc}} \\
1.1 \times 10^{4} \pm 1.0 \times 10^{3}\end{array}$ & $\begin{array}{c}7.1 \times 10^{3} \pm 1.0 \times 10^{2 \mathrm{~d}} \\
1.8 \times 10^{3} . \pm 1.0 \times 10^{2 \mathrm{~b}} \\
9.5 \times 10^{3} \pm 1.0 \times 10^{2}\end{array}$ & $\begin{array}{l}7.2 \times 10^{3} \pm 1.0 \times 10^{2 \mathrm{~cd}} \\
1.6 \times 10^{2} \pm 1.0 \times 10^{\mathrm{bc}} \\
7.0 \times 10^{3} \pm 1.0 \times 10^{2 \mathrm{c}}\end{array}$ & $\begin{array}{l}7.5 \times 10^{3} \pm 1 \times 10^{\text {cd }} \\
8.0 \times 10 \pm 1 \times 10^{\text {bc }} \\
8.5 \times 10^{3} \pm 1 \times 10^{2} .\end{array}$ \\
\hline
\end{tabular}

"Means sharing the same superscript are not significantly different from each other within the same row (Bonfferoni's, P<0.05)"

Note: TBC $=$ Total Bacterial Count, SSC $=$ Salmonella, Shigella Count, LBC $=$ Lactic Acid Bacteria Count, FC $=$ Fungal Count, NG $=$ No Growt

Table 2: Microbial succession during Baobab fruit pulp yoghurt fermentation

\begin{tabular}{|c|c|c|c|c|}
\hline Time (Hrs) & Bacteria & $\begin{array}{l}\text { Microbial Isolates } \\
\text { Lactic acid bacteria }\end{array}$ & Fungi & pH value \\
\hline 0 & Bacillus sp. Staphylococcus aureus & $\begin{array}{l}\text { Lacbacillus bulgaricus, } \\
\text { S. thermophilus }\end{array}$ & $\begin{array}{l}\text { Saccharomyces cerevisiae } \\
\text { Hansenula sp. }\end{array}$ & 6.1 \\
\hline 3 & $\begin{array}{l}\text { Micrococcus sp. Bacillus sp. } \\
\text { Staphylococcus aureus }\end{array}$ & $\begin{array}{l}\text { Lacbacillus bulgaricus, } \\
\text { S. thermophilus }\end{array}$ & $\begin{array}{l}\text { Saccharomyces cerevisiae } \\
\text { Hansenula sp. }\end{array}$ & 6.0 \\
\hline 6 & $\begin{array}{l}\text { Staph. aureus Lactobacillus } \\
\text { Micrococcus sp. Bacillus sp. }\end{array}$ & $\begin{array}{l}\text { S. thermophilus } \\
\text { Lacbacillus bulgaricus, }\end{array}$ & $\begin{array}{l}\text { Hansenula sp. } \\
\text { Saccharomyces cerevisiae }\end{array}$ & 5.9 \\
\hline 9 & $\begin{array}{l}\text { Micrococcus sp. Bacillus sp. } \\
\text { Lactobacillus sp. }\end{array}$ & $\begin{array}{l}\text { S. thermophilus } \\
\text { Lacbacillus bulgaricus }\end{array}$ & $\begin{array}{l}\text { Hansenula sp. } \\
\text { Saccharomyces cerevisiae }\end{array}$ & 4.9 \\
\hline 12 & $\begin{array}{l}\text { Bacillus sp. } \\
\text { Lactobacillus }\end{array}$ & $\begin{array}{l}\text { S. thermophilus } \\
\text { Lacbacillus bulgaricus }\end{array}$ & $\begin{array}{l}\text { Hansenula sp. } \\
\text { Saccharomyces cerevisiae }\end{array}$ & 4.8 \\
\hline 15 & $\begin{array}{l}\text { Bacillus sp. } \\
\text { Lactobacillus }\end{array}$ & $\begin{array}{l}\text { S. thermophilus } \\
\text { Lacbacillus bulgaricus }\end{array}$ & Saccharomyces cerevisiae & 4.6 \\
\hline
\end{tabular}


BAJOPAS Volume 13 Number 2,December, 2020

Table 3: Percentage Occurrence of Microbial Isolates of test and control Baobab fruit pulp Yoghurt

\begin{tabular}{|c|c|c|c|}
\hline Isolate & $\begin{array}{l}\text { Test } \\
\text { No. } 1 \% \text { t }\end{array}$ & $\begin{array}{c}\text { Control } \\
\text { No. }\{\%\}\end{array}$ & $\begin{array}{l}\text { Total } \\
\text { No. } 1 \% \%\end{array}$ \\
\hline Bacillus species & $03(6.5)$ & $05(12.2)$ & $08(9.2)$ \\
\hline Staphyocosens almeis & $04(8.7)$ & $06(14.6)$ & $10(11.5)$ \\
\hline Microcoecus species & $06(13.1)$ & $08(19.5)$ & $14(16.1)$ \\
\hline Lactic acid bacteria & $18(39.1)$ & $09(22.0)$ & $27(31.0)$ \\
\hline Saccharonices cerenisine & $05,17+4$ & $0 S(19.5)$ & $16(18.4)$ \\
\hline Hansemila species & $07(15,2)$ & $05(12.2)$ & $12(13.8)$ \\
\hline Total & $46(100)$ & $41(100)$ & $87(100)$ \\
\hline
\end{tabular}

No growth of Salmonella and Shigella was observed because of Pasteurization treatment and probably because of antimicrobial effect of constituents of the Baobab fruit pulp. Thisdisagrees with the finding of Eze et al (2014) who isolated diverse microorganisms including pathogenic organisms like Pseudomonas aeruginosa, Salmonella Spp, Aspergillus Sppetc from fermenting oil bean seeds.

The low total bacterial count obtained in this study as against higher count reported by De et al. (2014); Igbabul (2014) and Dirisu et al. (2015) whose reports showed high microbiological load in yoghurt sold in Central Market, Kaduna State, Makurdi metropolis, Benue State and Omoku Schools, Rivers State Nigeria respectively shows the microbial quality of this product.

Toward the end of fermentation of the product, there was decrease in all the microbial count except LBC which was observed to increase, this might be linked to increase in Lactic acid production and other inhibitory factors. This finding is in conformity with the report of Adams and Moss (2009) who reported the following as factors contributing to microbial inhibition by Lactic acid bacteria: Low $\mathrm{pH}$, Organic acids, Bacteriocins, Hydrogen Peroxides, Ethanol, Nutrient depletion and low redox potential.

At the end of the fermentation period (15hrs), the TBC and FC of the test group were found to have decreased while LBC was found to increase. There was more fungal count in the control than the test group probably because the test group recorded high count of Lactic Acid Bacteria which may produce large amount of lactic acids and bacteriocin that might have inhibitory effect on the growth of Yeasts like Saccharomyces cerevisiae and Hansenula Species (Thomas et al.,2001). The authors reported that yeast growth and fermentation rates could be adversely affected by the presence of high numbers of lactobacilli in incoming mash or in transfer lines.

Groups of microorganisms were isolated from the Baobab fruit pulp yoghurt. These included Bacillus species, Staphylococcus aureus, Lacbacillus bulgaricus, Saccharomyces cerevisiae, Streptococcus thermophilus, Hansenula species and Micrococcus species. The isolation of microorganisms like Bacillus species, Staphylococcus aureus and Micrococcus species could be due to post pasteurization contamination or their ability to survive pasteurization treatment. This result agrees with the submission of Adams and Moss (2009) who reported that members of the genera Microbacterium, Enterococcus, Micrococcus and Lactocillus can survive mild pasteurization treatment. $\mathrm{Ng}$ et al. (2010) also found out that pasteurized yoghurt had no effect on some bacterial strains. Saccharomyces cerevisiae was frequently encountered in the course of the fermentation and this position has since been observed by Adams and Moss (2009) that it is the most frequently encountered yeast in fermented beverages and foods based on fruits and vegetables. That all strains ferment glucose and many ferment other plant associated 
BAJOPAS Volume 13 Number 2,December, 2020 carbohydrates such as sucrose, maltose and raffinose.

The persistence of Bacillus species, Lacbacillus bulgaricus, Streptococcus thermophilus and Saccharomyces cerevisiae in the yoghurt up to the end of fermentation period could be due to their ability to produce bacteriocins and organic acids such as lactic acid, acetic acid etc which led to the decrease in $\mathrm{pH}$ (Jay, 2005). The organic acids, bacteriocin and low $\mathrm{pH}$ must have greatly contributed to the inhibition of the growth of other microorganisms especially pathogenic ones as opined by Caplice and Fitzgerald (1999) who reported that fermentation makes foods less hospitable to pathogenic microorganisms. Bacillus species though pathogenic, has been reported to produce bacteriocin which inhibit growth of other organisms but favours its growth.

The absence of Micrococcus species in the $12^{\text {th }}$ and $15^{\text {th }}$ hours of fermentation may not be

\section{REFERENCES}

Abdalla, A.A. Mohammed, M.A. and Mudawi, H.A. (2010). Production and Quality Assessment of Instant Baobab (Adansoniadigitata L.). Advance Journal of Food Science and Technology2(2):125 133.

Achi, O.K.,Anokwuru, I.C. and Ogbo, F.C. (2007). Microbiological and Chemical Changes during Fermentation of Crabs for ogirinsiko Production. American Journal of Food Technology, 2: 301-306.

Adams, M.R. and Moss, M.O. (2009). Food Microbiology. New Age International Publishers, Delhi, 389PP. ISBN 10: 0854046119/13: 9780854046119.

Baobab Fruit Company Senegal (BFCS): (2011). Baobab fruits. Accessed date: 08/06/2016 from http://www.patricksiki.com/en/services/w ebsite-development/

Bhattacharjee, S. (2013) Study of Microorganism in Milk(Dairy Microbiology)[Powerpoint slides]. Slideshare. http://www.slideshare.net/mobile/saugatb hatt/dairy-microbiology

Caplice, E. and Fitzgerald, G.F. (1999). Food fermentations: role of microorganisms in food production and preservation. International Journal of Food Microbiology. 15: 50(1-2):131 - 149.

Cheesbrough, M. (2000). District Laboratory Practice in Tropical Countries Part 2. unconnected to the continued presence of Bacillus species which has been reported to produce bacteriocin that Micrococcus species cannot withstand (Koncur et al., 2006).

\section{CONCLUSION}

This study reported low Microbial count and isolated less number and type of Microorganisms from Baobab Fruit Pulp Yoghurtbecause of the antimicrobial effect of baobab fruit pulp and Pasteurization treatment.The microbes isolated were all fermentative organisms except Bacillus species and Staphylococcus aureus which might be contaminants of the product.

Baobab Fruit Pulp Yoghurt can be said to be of good Microbiological quality for human consumption. The product if standardized can be marketed as a cheap source of income to the teeming Nigerian population.

Cambridge University Press, U.K. PP 62 70.

De, N., Goodluck, T.M. and Bobai, M. (2014). Micobiological quality assessment of bottled yoghurt at different brands sold in Central Market, Kaduna Metropolis, Kaduna, Nigeria. International Journal of Current Microbiology and Applied Sciences: 3(2):20 - 27.

Dirisu, C.G., Lily, G. and Igwe, E. (2015). Microbiological Load of Yoghurt Sold in Omoku Schools, Rivers State, Nigeria. African Journal of Microbiology Research. 9(34): $1960-1963$.

Efiosa, O. M. R., Chika, N. B. and Benedicta, A. (2017) Mineral and Proximate Composition of Soy bean. Asian Journal of Physical and Chemical Sciences, 4 (3): 1 - 6.

Ellis, D., Davis, S., Alexiou, H., Handke, R. and Bartley, R. (2007) Description of Medical Fungi $2^{\text {nd }}$ Ed. Nexus Print Solutions, Australia. 198PP

Eke, M. O., Olaitan, N. I. and Sule, H. I. (2013). Nutritional Evaluation of Yoghurt-Like Product from Baobab (Adansoniadigitata) Fruit Pulp Emulsion and the Micronutrient Content of Baobab Leaves, Advance Journal of Food Science and Technology5(10): 1266-1270.

Eze, V.C, Onwuakor, C.E, and Ukeka, E. (2014) "Proximate Composition, Biochemical and Microbiological Changes Associated with Fermenting African Oil Bean (Pentaclethramacrophylla Benth) Seeds." 
BAJOPAS Volume 13 Number 2,December, 2020 American Journal of Microbiological Research2(5): 138 - 142.

Helmenstine, A.M. (2016). What Is Fermentation? Definition, History, and Examples of Fermentation. http://chemistry.about.com/z/js/o.htm?k= foodfermentation.Accessed on $30^{\text {th }}$ November, 2016

Ibrahim, S. and Rahma, M. A. (2009). Isolation and Identification of Fungi associated with Date

Fruits (Phoenix Dactylifera, Linn.) sold at Bayero University, Kano, Nigeria. Bayero Journal of Pure and Applied Sciences,2(2): $127-130$

Igbabul, B., Shember, J. and Amove, J. (2014). Physicochemical, microbiological and sensory evaluation of yoghurt sold in Makurdi metropolis. African Journal of Food Science. Technology. 5(6):129 135.

Jay, J.M. (2005). Modern Food Microbiology $\left(4^{\text {th }}\right.$ Ed.). CBS Publishers and Distributors Pvt.Ltd. New Delhi. 700pp.

Koncur, M., Kloss, W.E. and Schliefer, K. (2006). The genus Micrococcus. Prokaryotes, 3, 961 - 971. Doi: 10.1007/springer reference -3714 .
Ng, E.W., Yeung, M. and Tong, P.S. (2010). Effects of Yoghurt starter cultures on the survival of Lactobacillusdigitalcommons.calpoly.edu/cgi/viewcontent.cgi?article $=1317 \&$ context $=$ bio-fac Accessed on $30^{\text {th }}$ November, 2016.

Parkouda, C., B/Hama, F., Ouattara/Songre, L., Tano-Debrah, K and Diawara, B. (2015). Biochemical changes associated with the fermentation of baobab seeds in Maari: An alkaline fermented seeds condiment from western Africa. Journal of ethnic food. 2(2):58 - 63 DOI: http://dx.doi.org/10.1016/j.jef.2015.04.00 2.

Thomas, K. C., Hynes, S. H. and Ingledew. W.M. (2001). Effect of Lactobacilli on yeast growth, viability and batch and semicontinuous alcoholic fermentation of corn mash. Journal of Applied Microbiology,90(5):819-828.

Vaughan, E. E., Caplice, E., Looney, R., O'Rourke, N., Coveney, H., Daly, C and Fitzgerald, G. F. (1994). Isolation from food sources, of lactic acid bacteria that produced antimicrobials, Journal of Applied Bacteriology.76 (2):118-23. 